University of Nebraska - Lincoln

DigitalCommons@University of Nebraska - Lincoln

Publications, Agencies and Staff of the U.S.

Department of Commerce

U.S. Department of Commerce

2011

\title{
A climatological analysis of heatbursts in Oklahoma (1994-2009)
}

Renee A. McPherson

University of Oklahoma Norman Campus

Justin D. Lane

NOAA/National Weather Service

Kenneth C. Crawford

University of Oklahoma Norman Campus

William G. McPherson Jr.

University of Oklahoma Norman Campus

Follow this and additional works at: https://digitalcommons.unl.edu/usdeptcommercepub

Part of the Environmental Sciences Commons

McPherson, Renee A.; Lane, Justin D.; Crawford, Kenneth C.; and McPherson, William G. Jr., "A climatological analysis of heatbursts in Oklahoma (1994-2009)" (2011). Publications, Agencies and Staff of the U.S. Department of Commerce. 290.

https://digitalcommons.unl.edu/usdeptcommercepub/290

This Article is brought to you for free and open access by the U.S. Department of Commerce at DigitalCommons@University of Nebraska - Lincoln. It has been accepted for inclusion in Publications, Agencies and Staff of the U.S. Department of Commerce by an authorized administrator of DigitalCommons@University of Nebraska - Lincoln. 


\title{
A climatological analysis of heatbursts in Oklahoma (1994-2009)
}

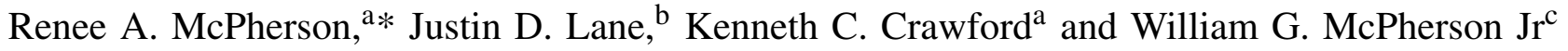 \\ a Oklahoma Climatological Survey, University of Oklahoma, Norman, OK, USA \\ b NOAA/National Weather Service, Greer, SC, USA \\ ${ }^{c}$ Center for Spatial Analysis, University of Oklahoma, Norman, OK, USA
}

\begin{abstract}
Heatbursts are characterized by a sudden and highly localized increase in air temperature, a simultaneous decrease in relative humidity and dewpoint temperature, and strong gusty winds, typically associated with decaying thunderstorms. The small spatial extent and short duration of most heatbursts makes detailed study of these events difficult using the standard federal observation network (e.g. hourly observations) established in most countries. Thus, many discussions of heatbursts note that they are 'rare' phenomena. However, observations from the Oklahoma Mesonet indicate that although heatbursts are meso-alpha scale phenomena, they are not rare. Using multi-criteria analysis, 207 heatburst events of various magnitudes, areal coverage and duration were identified between 1994 and 2009 across Oklahoma. Significantly more heatbursts were detected in the western two-thirds of the state as compared to the eastern third. Heatbursts were primarily nocturnal events, with $70 \%$ of heatburst events initiated between 0000 and 0800 UTC (i.e. between 6 p.m. and 2 a.m. Central Standard Time). With 62 of the 207 events, June was the most active month for heatbursts. At the other extreme, no heatbursts were detected during February and November, and only one was observed during January and December. Almost all of the heatbursts occurred underneath or adjacent to weak radar echoes at the time of the event. Four basic radar patterns were associated with the events: (1) radar echoes associated with rapidly weakening convection, (2) weak reflectivity not produced by or associated with deep moist convection, (3) weak radar echoes to the rear of a dissipating mesoscale convective system (MCS) and (4) weak reflectivity along the periphery of intense convection that did not appear to be weakening. Copyright (C) 2010 Royal Meteorological Society
\end{abstract}

KEY WORDS heatburst; heat burst; Oklahoma Mesonet; multi-criteria analysis

Received 12 September 2009; Revised 17 December 2009; Accepted 18 December 2009

\section{Introduction}

Decaying nocturnal thunderstorms can produce hot, dry and gusty surface winds that have been called warm wakes by Williams (1963), hot blasts by Froude and Simmonds (1965), heat bursts by Johnson (1983) and heatbursts by Lane (2000). Most of the documented heatbursts occurred in the Great Plains of the United States during the warm season, typically between 0000 and 1200 UTC, and were associated with weak or dissipating radar echoes (e.g. Cline, 1909; Sloan, 1966; Wood, 1966; Johnson et al., 1989; McNulty, 1991; Johnson, 2004; Trobec, 2008).

Heatbursts are characterized by a sudden and highly localized increase in air temperature, a simultaneous decrease in relative humidity and dewpoint temperature, and strong gusty winds. Air pressure typically decreases during the event. Heatbursts have occurred on time scales that range from several minutes to several hours, with sudden temperature increases as high as $13^{\circ} \mathrm{C}$

* Correspondence to: Renee A. McPherson, University of Oklahoma, Oklahoma Climatological Survey, 120 David L. Boren Blvd., Suite 2900, Norman, OK 73072, USA.

E-mail: renee@ou.edu
(Cunningham, 1989), relative humidity decreases as large as $83 \%$ (Cunningham, 1989) and wind gusts as strong as $47 \mathrm{~m} \mathrm{~s}^{-1}$ (MacKeen et al., 1998).

The primary objectives of the research documented herein were as follows: (1) to identify benefits and challenges of applying an automated technique to heatburst detection, (2) to document and discuss the temporal distribution (i.e. monthly and hourly) of Oklahoma heatbursts and (3) to document and discuss the spatial distribution of Oklahoma heatbursts. Diagnosis of heatburst dynamics, using the extensive set of cases found in this study, will be an important contribution to understanding the evolution and environment of these events; however, it is beyond the scope of this research.

For this study, a 'heatburst' was designated by a set of binary criteria for air temperature change, dewpoint temperature change, and wind gusts, detailed in Section 3.2. A 'heatburst detection' was defined as the diagnosis of a heatburst or short series of heatbursts at a surfaceobserving station. A 'heatburst event' was defined as a heatburst or short series of heatbursts that affected one or more surface-observing stations during a single day and showed temporal and spatial continuity. Hence, a single heatburst event might coincide with multiple 
heatburst detections. Heatbursts that affected multiple stations during the same day but lacked temporal or spatial continuity with one another were treated as separate heatburst events.

Using data from the Oklahoma Mesonet (Brock et al., 1995; McPherson et al., 2007), we document 308 heatburst detections, corresponding to 207 heatburst events, across Oklahoma, from 1 January 1994 to 15 August 2009. Many heatburst events affected only one observing site and lasted only $20 \mathrm{~min}$; some were sensed at more than 10 observing stations and persisted for several hours.

In rare instances, heatbursts posed a risk to public safety and property. For example, a prolonged heatburst event on 23 May 1996 caused severe winds that resulted in approximately $\$ 18$ million in damage across southwest and central Oklahoma. A less intense event on 7 July 1995 in northeast Oklahoma caused approximately $\$ 2$ million in damage and a minor injury as a large boat dock, with 20 boats attached and 50 people on board, was thrown $15 \mathrm{~m}$.

\section{Historical overview of heatbursts}

Detailed studies of the temporal and spatial scales of heatbursts have been limited because of a shortage of dense surface-observing networks. Previous studies were based on either an event that affected a single synoptic observation station or an event that occurred across a temporary mesoscale network. Most of these events were documented across the Southern Great Plains of the United States. However, one of the strongest heatbursts ever recorded, in terms of temperature and humidity changes alone, occurred in Guernsey, United Kingdom on 31 July 1983 (Cunningham, 1989). Table I summarizes heatbursts discussed in the meteorological literature.

The earliest documented heatburst (Cline, 1909) occurred in Cherokee, Oklahoma, during the late evening/ early morning of 11 July 1909. Described as a 'hot wind', the surface temperature reportedly increased to more than $57^{\circ} \mathrm{C}$. [Note: the accuracy of this measurement is disputed because Oklahoma's record maximum temperature, accepted in climatological records, is $48.9^{\circ} \mathrm{C}$.] The localized nature of the temperature increase, the time of day and the area where the event occurred pointed to the likelihood that this phenomenon was a heatburst. Not surprisingly, the explanation given for the event was rather general, as Cline attributed the heating to a very narrow and intense current of downsloping air from the Rocky Mountains.

Over 50 years after the first report of an apparent heatburst, Williams (1963) documented several 'warm wakes' in south-central Oklahoma, as detected by an experimental network operated for 3 years by the National Severe Storm Project. One such event, on 4 May 1961, produced local temperature increases of $6.1{ }^{\circ} \mathrm{C}$ and relative humidity decreases as large as $45 \%$. The phenomenon resulted from a warm, dry downdraft that coincided with a mesoscale area of low pressure in the echofree area at the trailing edge of a dissipating thunderstorm. Williams proposed that the warm wake represented warm, dry air, produced by subsidence aloft, that was transported to the surface in a subsidence region between the meso-low and the thunderstorm.

Table I. Heatburst events in the meteorological literature.

\begin{tabular}{|c|c|c|c|c|c|}
\hline Author & Date & Time & Location & Weather Observed & Explanation \\
\hline Cline (1909) & 11 Jul 1909 & 0600-0800 UTC & $\begin{array}{l}\text { Cherokee, } \\
\text { Oklahoma }\end{array}$ & $\begin{array}{l}\mathrm{T}_{\text {air }} \text { reportedly } \\
\text { increased to } 57^{\circ} \mathrm{C}\end{array}$ & $\begin{array}{l}\text { Described as a } \\
\text { narrow, intense } \\
\text { current of } \\
\text { downsloping wind }\end{array}$ \\
\hline Williams (1963) & 4 May 1961 & 0600-1000 UTC & $\begin{array}{l}\text { Southern } \\
\text { Oklahoma }\end{array}$ & $\begin{array}{l}\mathrm{T}_{\text {air }} \text { increases of } \\
\text { over } 6^{\circ} \mathrm{C}, \mathrm{RH} \\
\text { decreases of } 45 \%\end{array}$ & $\begin{array}{l}\text { Subsidence from a } \\
\text { dissipating } \\
\text { thunderstorm }\end{array}$ \\
\hline Wood (1966) & 25 May 1963 & 0600-0800 UTC & Midland, Texas & $\begin{array}{l}\mathrm{T}_{\text {air }} \text { increase of } \\
6.7^{\circ} \mathrm{C}, \mathrm{RH} \\
\text { decrease, gusty } \\
\text { winds, pressure } \\
\text { decrease }\end{array}$ & $\begin{array}{l}\text { Subsidence from a } \\
\text { dissipating } \\
\text { thunderstorm }\end{array}$ \\
\hline $\begin{array}{l}\text { Froude and } \\
\text { Simmons (1965) }\end{array}$ & 29 Jun 1964 & $1100 \mathrm{UTC}$ & Aden, S. Yemen & $\begin{array}{l}\mathrm{T}_{\text {air }} \text { increase of } \\
11^{\circ} \mathrm{C} \text {, gusty winds }\end{array}$ & None given \\
\hline Sloan (1966) & 15 Jun 1965 & Late Evening & Midland, Texas & $\begin{array}{l}\mathrm{T}_{\text {air }} \text { increase of } \\
7.8^{\circ} \mathrm{C}\end{array}$ & $\begin{array}{l}\text { Adiabatic } \\
\text { downdraft from a } \\
\text { small, dissipating } \\
\text { cumulonimbus }\end{array}$ \\
\hline Johnson (1983) & 30 May 1976 & $1200 \mathrm{UTC}$ & Oklahoma & $\begin{array}{l}\mathrm{T}_{\text {air }} \text { increases of } \\
5^{\circ} \mathrm{C}, \mathrm{RH} \text { decreases } \\
\text { of } 50 \% \text {, winds } \\
\text { gusting to } 26 \mathrm{~m} \\
\mathrm{~s}^{-1}\end{array}$ & $\begin{array}{l}\text { Thunderstorm } \\
\text { downburst } \\
\text { affecting } \\
\text { surface-based } \\
\text { inversion }\end{array}$ \\
\hline
\end{tabular}


Table I. (Continued).

\begin{tabular}{|c|c|c|c|c|c|}
\hline Author & Date & Time & Location & Weather Observed & Explanation \\
\hline $\begin{array}{l}\text { Cunningham } \\
\text { (1989) }\end{array}$ & 31 Jul 1983 & 0000-0700 UTC & Guernsey, UK & $\begin{array}{l}\mathrm{T}_{\text {air }} \text { increase of } \\
13^{\circ} \mathrm{C}, \mathrm{RH} \\
\text { decrease of } 80 \% \text {, } \\
\text { pressure drop of } \\
7 \mathrm{hPa}\end{array}$ & None given \\
\hline $\begin{array}{l}\text { Johnson et al. } \\
\text { (1989) }\end{array}$ & 24 Jun 1985 & 1300 UTC & Oklahoma & $\begin{array}{l}\mathrm{T}_{\text {air }} \text { increases of } \\
2-4{ }^{\circ} \mathrm{C} \text {, dewpoint } \\
\text { decrease, pressure } \\
\text { decrease }\end{array}$ & $\begin{array}{l}\text { Downburst } \\
\text { affecting surface } \\
\text { inversion }\end{array}$ \\
\hline $\begin{array}{l}\text { Bernstein and } \\
\text { Johnson (1994) }\end{array}$ & 24 Jun 1985 & 0000-0400 UTC & Oklahoma & $\begin{array}{l}\mathrm{T}_{\text {air }} \text { increases of } \\
2-4{ }^{\circ} \mathrm{C} \text {, dewpoint } \\
\text { decrease, pressure } \\
\text { decrease }\end{array}$ & $\begin{array}{l}\text { Downward branch } \\
\text { of rear inflow jet } \\
\text { affecting surface } \\
\text { inversion }\end{array}$ \\
\hline McNulty (1991) & 4 Mar 1990 & 1100 UTC & Goodland, Kansas & $\begin{array}{l}\mathrm{T}_{\text {air }} \text { increase of } \\
7.8^{\circ} \mathrm{C} \text {, wind gust } \\
\text { of } 18.3 \mathrm{~m} \mathrm{~s}^{-1}\end{array}$ & $\begin{array}{l}\text { Downburst from } \\
\text { cumulus affecting } \\
\text { surface inversion }\end{array}$ \\
\hline $\begin{array}{l}\text { MacKeen et al. } \\
\text { (1998) }\end{array}$ & 23 May 1996 & 0000-0700 UTC & Oklahoma & $\begin{array}{l}\mathrm{T}_{\text {air }} \text { increases of } \\
7{ }^{\circ} \mathrm{C}, \mathrm{T}_{\text {dew }} \\
\text { decreases of } 15^{\circ} \mathrm{C} \text {, } \\
\text { wind gusts of } \\
47 \mathrm{~m} \mathrm{~s}^{-1}\end{array}$ & None given \\
\hline $\begin{array}{l}\text { Instituto Nacional } \\
\text { de Meteorología } \\
\text { de España }\end{array}$ & $23 \mathrm{Jul} 2001$ & 1000-1200 UTC & Melilla, Spain & $\begin{array}{l}\mathrm{T}_{\text {air }} \text { increase of } \\
17^{\circ} \mathrm{C} \text {, pressure } \\
\text { decrease of } 2 \mathrm{hPa} \\
\text { and } 19.4 \mathrm{~m} \mathrm{~s}^{-1} \\
\text { wind gust; } 15^{\circ} \mathrm{C} \\
\mathrm{T}_{\text {air increase in }} \\
\text { second event }\end{array}$ & $\begin{array}{l}\text { Heatburst or } \\
\text { downslope winds } \\
\text { in presence of } \\
\text { altocumulus with } \\
\text { warm, dry air } \\
\text { below } 500 \mathrm{hPa}\end{array}$ \\
\hline Johnson (2004) & $30 \mathrm{Jul} 2001$ & 0700-1500 UTC & $\begin{array}{l}\text { Northern Nebraska } \\
\text { and Southern } \\
\text { South Dakota }\end{array}$ & $\begin{array}{l}\mathrm{T}_{\text {air }} \text { increase of } \\
4-7{ }^{\circ} \mathrm{C}, \mathrm{RH} \\
\text { decrease of } 15 \% \text {, } \\
\text { and winds gusting } \\
\text { to } 19-28 \mathrm{~m} \mathrm{~s}^{-1} \text { in } \\
\text { a series of } \\
\text { heatbursts }\end{array}$ & $\begin{array}{l}\text { Decay of a } \\
\text { mesoscale } \\
\text { convective system }\end{array}$ \\
\hline $\begin{array}{l}\text { Azorín Molina } \\
\text { (2005) }\end{array}$ & 30 Jun 2004 & $1730-2130$ UTC & Alicante, Spain & $\begin{array}{l}\mathrm{T}_{\text {air }} \text { increases of } \\
2.0-9.1^{\circ} \mathrm{C}, \mathrm{RH} \\
\text { decreases of } \\
16-40 \%\end{array}$ & $\begin{array}{l}\text { Dissipating } \\
\text { thunderstorms }\end{array}$ \\
\hline Trobec (2008) & 11 Aug 2007 & 0700-0900 UTC & $\begin{array}{l}\text { Sioux Falls, South } \\
\text { Dakota }\end{array}$ & $\begin{array}{l}\mathrm{T}_{\text {air }} \text { increase of } \\
7^{\circ} \mathrm{C}, \mathrm{T}_{\text {dew }} \\
\text { decreases of } 12{ }^{\circ} \mathrm{C} \text {, } \\
\text { winds gusting to } \\
21 \mathrm{~m} \mathrm{~s}^{-1}\end{array}$ & $\begin{array}{l}\text { Decaying } \\
\text { thunderstorms }\end{array}$ \\
\hline
\end{tabular}

Wood (1966) reported an apparent warm wake near Midland, Texas, when a dissipating thunderstorm produced a 20-min temperature increase of $6.7^{\circ} \mathrm{C}$ during the early morning hours of 24 May 1963 . Wood concluded that the warm, dry air resulted from subsiding air that originated near $850 \mathrm{hPa}$. Sloan (1966) documented a similar event near Midland. On 15 June 1965, surface temperatures increased $7.8-30.6^{\circ} \mathrm{C}$ just after 1200 UTC. The warming was accompanied by a significant decrease in relative humidity, but no unusual wind activity was reported. It was hypothesized that the warming and drying resulted from adiabatic descent from a small, dissipating cumulonimbus nearby the observing station. Analysis of the Midland sounding from 1200 UTC showed that the warm surface air would have had to originate near $500 \mathrm{hPa}$ to achieve warming of the magnitude observed.

A series of airline disasters during the 1970s were attributed to severe wind shear, leading to work by Fujita to examine the mechanisms responsible for such extreme events. Fujita and Byers (1977) discovered that these accidents resulted from unusually strong downdrafts, labeled 'downbursts', that occurred at the time of each disaster. Fujita and Caracena (1977) first defined the downburst for aviation purposes; Fujita (1978) then defined a downburst meteorologically as a strong 

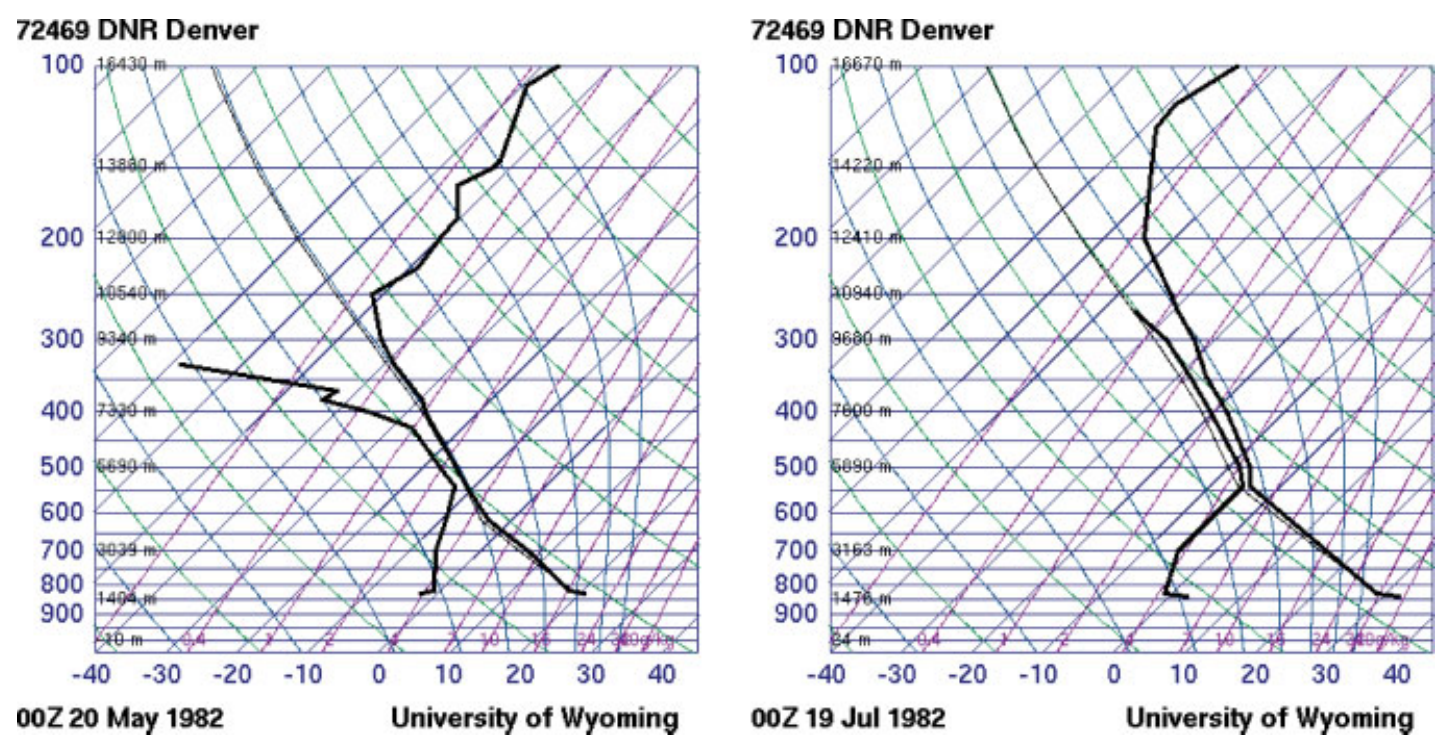

Figure 1. Examples of a 'Type A' sounding typically associated with dry microbursts across the high plains of the United States. The moist layer at $500 \mathrm{hPa}$ tops a deep and very dry mixed layer. These features create an environment conducive to evaporatively driven, dry downdrafts. The evening soundings shown were measured at Denver, Colorado, on 20 May 1982 (left) and 19 July 1982 (right) at 0000 UTC, $1 \mathrm{~h}$ later than those displayed in Wakimoto (1985). Images courtesy of the University of Wyoming. This figure is available in colour online at wileyonlinelibrary.com/journal/joc

downdraft that produced an outburst of damaging winds on or near the ground. Fujita (1978) also introduced the 'microburst', defined as a downburst with horizontal extent $<4 \mathrm{~km}$ and duration $<5 \mathrm{~min}$. Caracena et al. (1983), Wakimoto (1985), and others further classified microbursts into 'dry' and 'moist' categories that depended on the amount of rainfall during the event. A representative sounding (Type A; Wakimoto, 1985) for an environment conducive to dry microburst development is very dry, dominated by a dry adiabatic lapse rate below $500 \mathrm{hPa}$, and with an elevated moist layer near $500 \mathrm{hPa}$ (Figure 1). Dry microbursts are relatively common during the summer throughout the High Plains of the United States, especially during the daytime.

Johnson (1983) analysed a heatburst event across portions of Oklahoma on 29 and 30 May 1976, measured by a mesonetwork established by the National Severe Storms Laboratory (NSSL). Heatburst conditions progressed from Mangum (southwest Oklahoma) just after 2300 UTC on 29 May, to Tulsa (northeast Oklahoma, about $350 \mathrm{~km}$ from Mangum) after $0500 \mathrm{UTC}$ on 30 May. Temperature increases as large as $5^{\circ} \mathrm{C}$, relative humidity decreases of $50 \%$ and wind gusts in excess of $25 \mathrm{~m} \mathrm{~s}^{-1}$ were associated with the bursts. In this instance, the heatbursts were associated with dissipating radar echoes.

Johnson noted that the environmental wind shear associated with the event was similar to that of a downburst. She also observed that soundings acquired in the vicinity of these heatbursts showed a dry, mostly dry adiabatic thermodynamic profile below $500 \mathrm{hPa}$, with a shallow layer of moist air around $500 \mathrm{hPa}$ - similar to the 'Type A' sounding (Figure 1). The fundamental difference between the soundings Johnson analysed and the typical Type A sounding was the presence of a

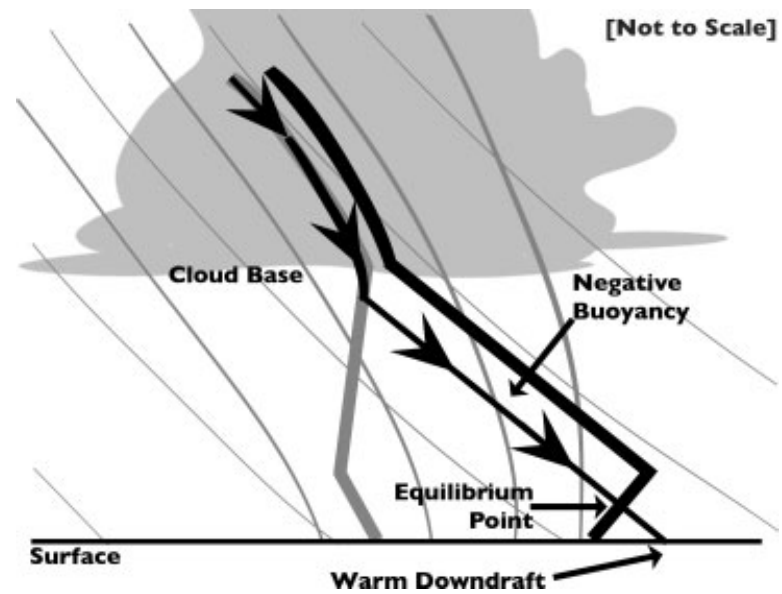

Figure 2. Illustration of an idealized microburst that produces a heatburst at the surface (after Johnson, 1983). The thick black line represents the environmental temperature profile; the thick gray line represents the dewpoint temperature profile; light solid lines are dry adiabats; medium solid lines are moist adiabats; and the line of arrows represents the thermodynamic path of the downdraft. Evaporational cooling initiates descent to below cloud level. Because of the dry adiabatic nature of the sub-cloud layer, the downdraft sinks dry adiabatically until it reaches its equilibrium point. If the downdraft possesses sufficient momentum, it surpasses its equilibrium point and reaches the surface, where it is warmer than the environmental profile.

shallow, surface-based inversion on the 30 May 1976 sounding (see Johnson, 1983).

Johnson proposed the following sequence of events that preceded heatburst development (Figure 2): (1) rain from a high-based convective cloud descended moist adiabatically into very dry air below cloud level then completely evaporated, cooling a small region of environmental air; (2) as air parcels descended dry adiabatically, they remained cooler than their environment (given 
the presence of environmental lapse rates that were dry adiabatic) and (3) in the presence of a surface-based temperature inversion and with sufficient downdraft momentum, the descending air could continue downward beyond its equilibrium level to reach the surface. In this scenario, when the downdraft contacted the ground, its air parcels were warmer than its surrounding, surface-based environment. Hence, Johnson described heatbursts as essentially downbursts or microbursts that penetrated a surface-based temperature inversion. This explanation is consistent with the nocturnal nature of heatburst events because nighttime inversions are almost always present. In addition, this scenario could explain why most decaying thunderstorms do not produce heatbursts because weak surface-based inversions must coexist with downdraft velocities strong enough to penetrate the surface inversion.

Cunningham (1989) described one of the more extraordinary heatburst events discussed in the meteorological literature. On 31 July 1983, between 1250 and 1320 UTC in Guernsey, United Kingdom, temperatures increased from 16 to $29^{\circ} \mathrm{C}$ and relative humidity decreased from nearly $100 \%$ to $16.5 \%$. Reports included a pressure drop of $7 \mathrm{hPa}$ and a wind gust of $32.4 \mathrm{~m} \mathrm{~s}^{-1}$. Cunningham did not attempt to offer an explanation for the phenomenon, but did describe the weather as being of a 'thundery nature' at the time of the event. The event is interesting for its severity, time of day and the area of the world where it occurred.

Johnson et al. (1989) and Bernstein and Johnson (1994) analysed a heatburst event that occurred on 23-24 June 1985 over a mesonetwork for the Oklahoma-Kansas Preliminary Regional Experiment for STORM-Central (PRE-STORM). Several heatbursts, lasting between 15 and $70 \mathrm{~min}$, were observed during the evening hours within a meso-low that trailed a dissipating MCS. Johnson et al. noted temperature increases of $2-4^{\circ} \mathrm{C}$ and dewpoint temperature decreases as large as $10^{\circ} \mathrm{C}$. Environmental soundings were almost identical to the soundings used by Johnson (1983).

Incorporating dual Doppler radar data, Bernstein and Johnson (1994) provided a somewhat different explanation for the source of subsiding air than Johnson et al. (1989). The dual Doppler analysis indicated the presence of a rear inflow jet that laterally entered the stratiform region of the MCS from the south. The authors proposed that the subsiding branch of this jet might have been responsible for the heatbursts. This observation implies that a heatburst could result from any mechanism capable of producing sinking dry air with sufficient momentum to penetrate a shallow, surface-based inversion to reach the surface.

Finally, McNulty (1991) described an incident that occurred on 4 March 1990 in Goodland, Kansas. The National Weather Service (NWS) Office at Goodland reported an apparent microburst at 1048 UTC when a wind gust of $18.3 \mathrm{~m} \mathrm{~s}^{-1}$ occurred. The only radar echoes detected by the Goodland radar were an area of dissipating light rain showers and snow showers along the Kansas-Colorado border. Although McNulty did not refer to the event as a heatburst, a temperature increase of $7.8^{\circ} \mathrm{C}$ was observed along with the gusty winds. An interpolated sounding valid for the time of the Goodland microburst revealed the presence of a shallow, surface-based inversion as well as the classic structure of an environment conducive to microburst development. The Goodland event demonstrated that (1) although heatbursts are predominantly warm season events, they can occur in the winter months; and (2) the presence of a dissipating thunderstorm is not vital for heatburst development.

These previous studies focused on analysis of single events, and while they offered significant insight to heatbursts and their environment, they did not address the temporal or spatial distribution of heatbursts near their study region. In addition, although these studies documented ranges of environmental conditions that occurred during a heatburst, none of the researchers identified specific criteria that could identify heatburst conditions. Specific criteria could be used to automatically detect a heatburst, resulting in near-real-time alerts for the public. Lane (2000) started to address these issues using data across Oklahoma from October 1993 through September 1998. This study expands his work to a substantially larger data set (i.e. 107-120 surface mesonet stations with 5-min atmospheric measurements over almost 15 years), allowing for more robust analysis.

\section{Methodology}

\subsection{Data from the Oklahoma Mesonet}

Jointly owned by the University of Oklahoma and Oklahoma State University, the Oklahoma Mesonet has measured hydrological, agricultural and meteorological variables at 5-min intervals since 1994 (Brock et al., 1995; McPherson et al., 2007). Each of the automated surfaceobserving stations of the Oklahoma Mesonet monitors and gathers more than 20 meteorological variables, including temperature, relative humidity, wind speed and direction, barometric pressure and rainfall. The number of Mesonet stations at a given time has ranged from 107 to 120 (Figure 3) since the network became operational on 1 January 1994. The data set for this study included all archived Oklahoma Mesonet data from 1 January 1994 through 15 August 2009.

The Oklahoma Mesonet measured relative humidity with a Vaisala combination thermistor-sorption HMP35C probe until 2005, when a network-wide upgrade to Vaisala's HMP45C was completed. The manufacturer's specified accuracy for both sensors is $\pm 2 \%$ between values of $0-90 \%$, and $\pm 3 \%$ between 90 and $100 \%$. Prior to 2004, air temperature at $1.5 \mathrm{~m}$ was measured by the HMP35C. On 1 January 2004, the network transitioned to a Thermometrics' Unitherm Interchangeable Thermistor DC95 (operating range of -30 to $50^{\circ} \mathrm{C}$; accuracy of $\pm 0.4^{\circ} \mathrm{C}$ ) for all air temperature measurements. R. M. Young multi-plate, unaspirated radiation shields housed both air temperature sensors until 2009, when a 


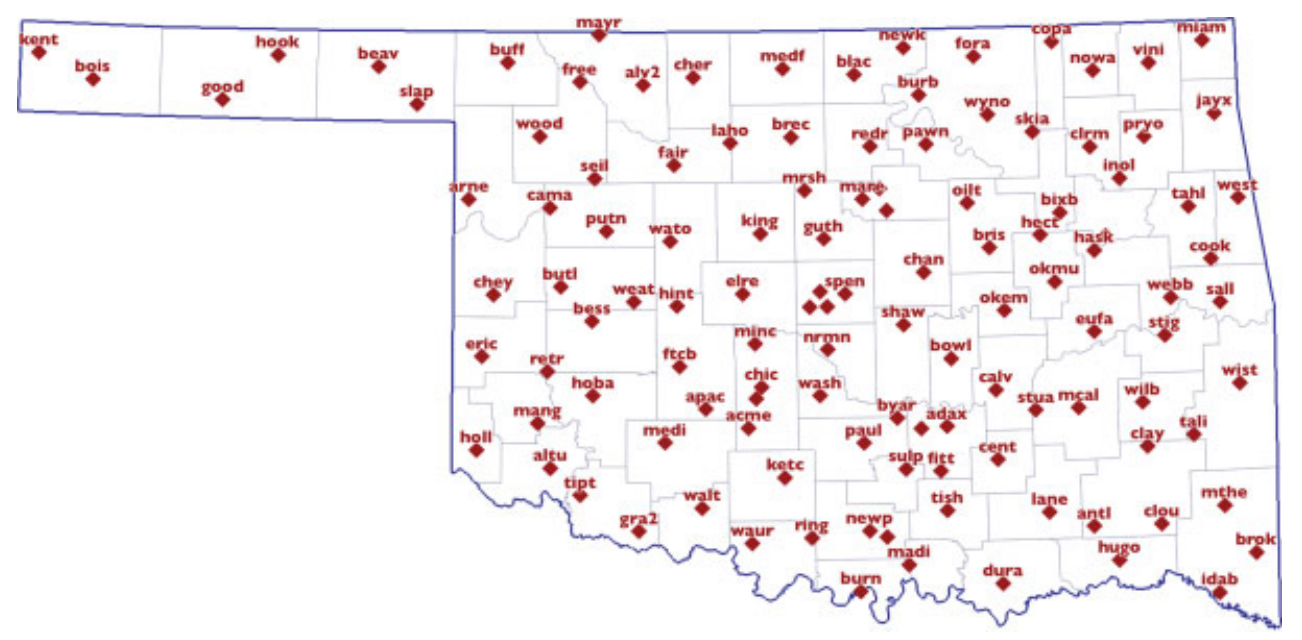

Figure 3. Locations of Oklahoma Mesonet stations as of August 2009. Data from these surface-observing stations, as well as several previously decommissioned stations (e.g. site moves, project termination), were used in this study. Four-letter identifiers are shown above most of the stations. This figure is available in colour online at wileyonlinelibrary.com/journal/joc

system-wide upgrade began to substitute R. M. Young 43502 aspirated shields.

Wind observations at $10 \mathrm{~m}$ always have been measured with the R. M. Young 5103 wind monitor (operating range of 1.0 and $60.0 \mathrm{~m} \mathrm{~s}^{-1}$; accuracy of $\pm 0.3 \mathrm{~m} \mathrm{~s}^{-1}$ ). Other sensors of the Oklahoma Mesonet are detailed in McPherson et al. (2007).

\subsection{Heatburst criteria and associated definitions}

A multi-criteria analysis (Malczewski, 1999) was conducted to identify potential heatbursts from the data archives. The following binary criteria were selected because of their consistency with past observations of heatbursts:

1. An increase in air temperature of $2.7^{\circ} \mathrm{C}$ during a 10 min period.

2. A simultaneous decrease in dewpoint temperature of $2.7^{\circ} \mathrm{C}$.

3. A maximum wind gust of at least $10 \mathrm{~m} \mathrm{~s}^{-1} 5 \mathrm{~min}$ prior to, during, or $5 \mathrm{~min}$ after the thermodynamic perturbations.

For this study, a 'heatburst day' was defined as a UTC day (0000 UTC to 2359 UTC) when one or more heatbursts were detected at one or more stations within the Oklahoma Mesonet. A 'heatburst detection' was defined as the detection of heatburst conditions using the above criteria at an individual Mesonet station. A 'heatburst event' was defined as a heatburst or short series of heatbursts that (1) affected one or more Mesonet stations during a single heatburst day and (2) demonstrated temporal and spatial continuity. Because discrete surface observations were used in this study, the latter condition was assessed qualitatively by examining animations (at 5-min resolution) of composite maps using both Oklahoma Mesonet and radar base reflectivity data. Heatburst conditions within a single event (especially longer duration events) typically propagated both outward from the location of heatburst initiation and laterally in the direction of storm motion. This qualitative method introduced a possible source of error to the number of heatburst events analysed in this study.

Using archived data, the search detected 390 potential heatburst days during the 15.6-year period. Upon manual inspection, 226 of the 390 days were determined to be instances of dryline passage, frontal passage or a thermodynamic change in response to either a rapid increase in solar radiation during the morning hours or the passage of a daytime precipitation system. The remaining 164 event days could not be attributed to these phenomena and, thus, were identified as heatburst days. On the 164 heatburst days from 1 January 1994 to 15 August 2009, we document 308 heatburst detections, corresponding to 207 heatburst events. Multiple Mesonet sites met the heatburst criteria on 61 of the 164 heatburst days. Multiple heatburst events occurred on 30 of these 61 days.

For each heatburst detection, manual analysis of maps and time series determined the onset, peak and end of heatburst conditions. The peak of heatburst conditions simply was the time of the maximum observed temperature at the given station. The onset of the heatburst detection was defined as the time when the air temperature began to increase with no subsequent decrease until after the peak of the event. A downward trend in dewpoint temperature that began prior to or simultaneous with the temperature increase also was necessary to meet the onset criteria.

Detection of the end of the heatburst was more difficult. In many cases, the anomalously warmer and drier air stayed in the areas for $1 \mathrm{~h}$ or more without any apparent thermodynamic forcing beyond the main downdraft. A combination of manual examination of map animations and time series plots was used to estimate when the heatburst stopped affecting the temperature and dewpoint of the given station in comparison to its larger scale environment. 


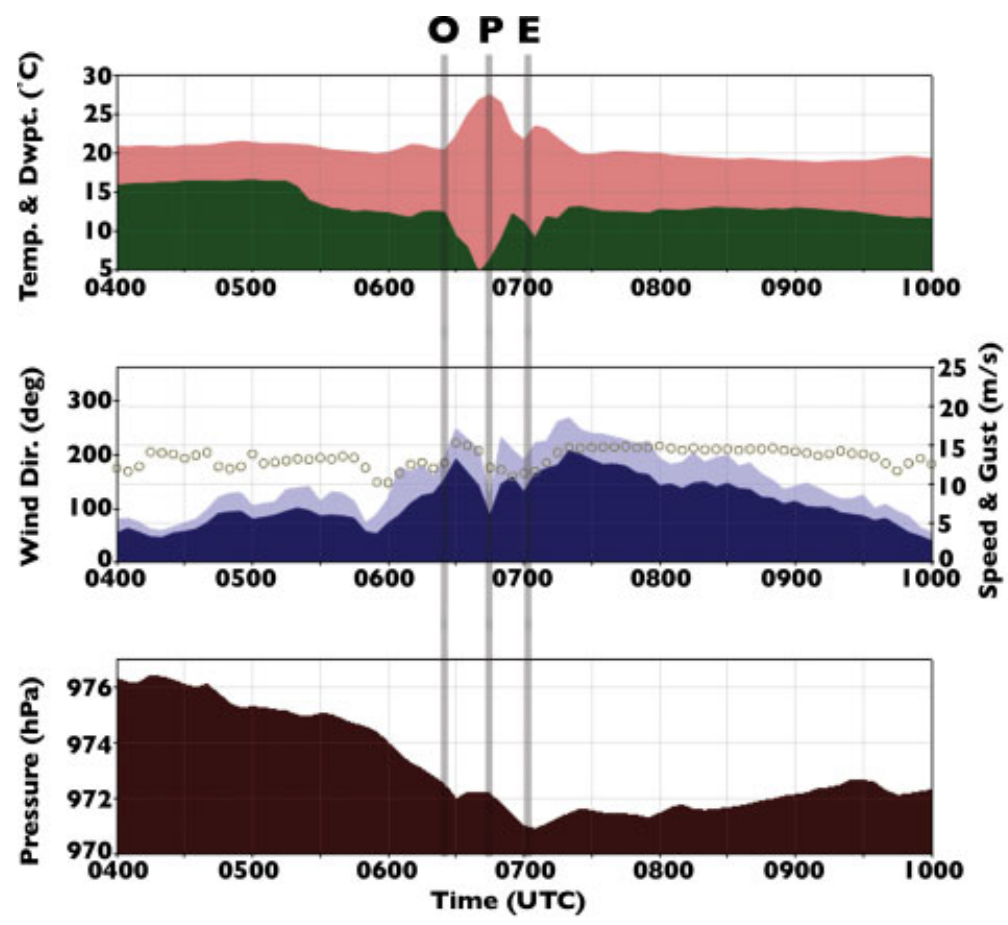

30 April 2003

0640 UTC
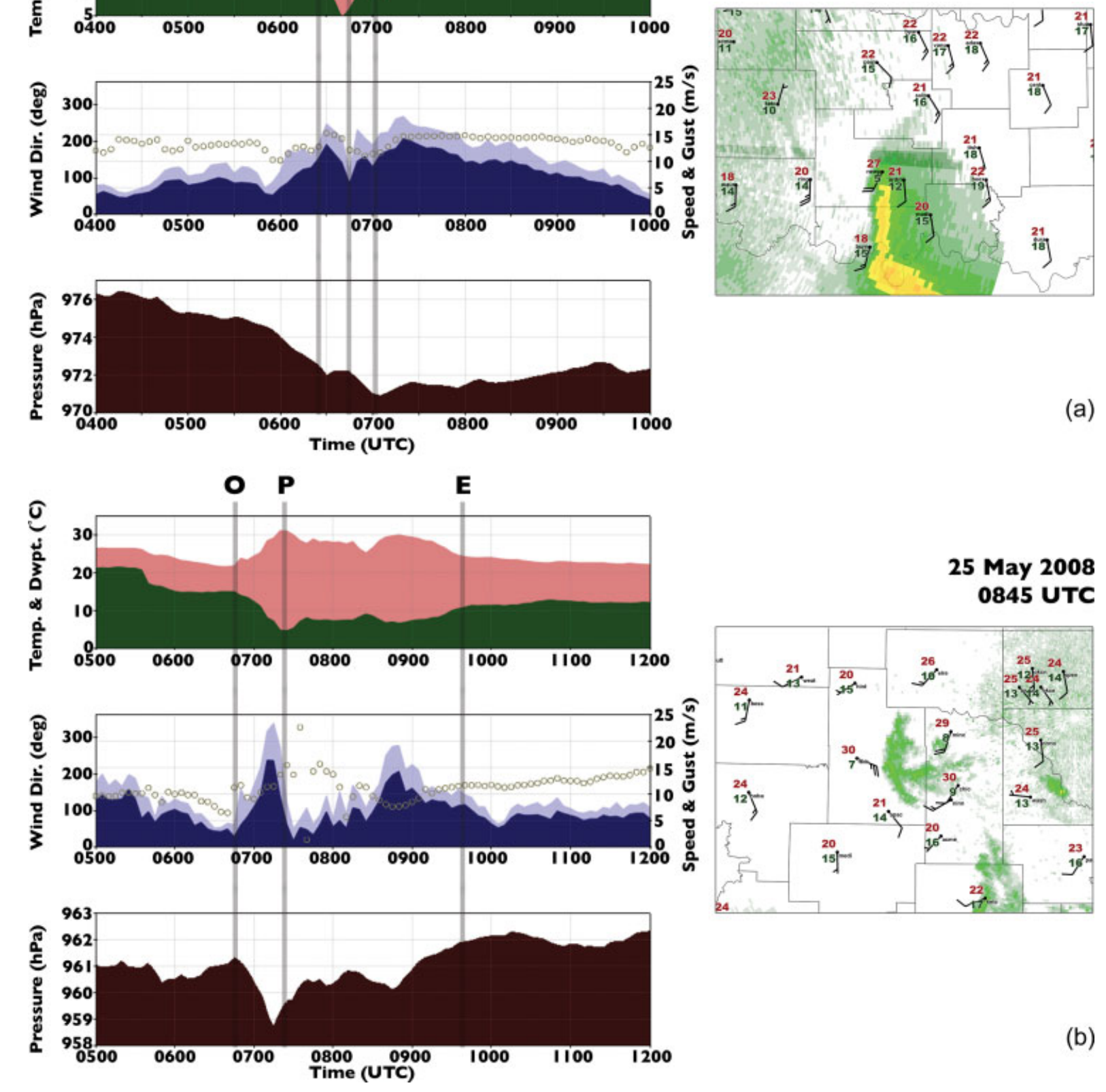

(a)

Figure 4. (a) Example of a heatburst event consisting of heatburst conditions at a single station (Newport, left, on 30 April 2003) and (b) example of an event with heatburst conditions at multiple stations (Fort Cobb, left, Chickasaw, and Minco on 25 May 2008). For each graph, the top panel represents dry-bulb (light shading) and dewpoint (dark shading) temperatures in degree celsius; the middle panel displays wind speed (dark shading) and gusts (light shading) in $\mathrm{m} \mathrm{s}^{-1}$ as well as wind direction (dots) in degrees from North; and the bottom panel shows station pressure in $\mathrm{hPa}$. This figure is available in colour online at wileyonlinelibrary.com/journal/joc

\subsection{Examples of heatburst events}

Figure 4 illustrates two heatburst events: (1) an event consisting of heatburst conditions at a single station (Figure 4a) and (2) an event with heatburst conditions at multiple stations (Figure 4b). The representative graphs and maps show typical thermodynamic perturbations associated with an Oklahoma heatburst.

\section{Characteristics of Oklahoma heatbursts (1994-2009)}

\subsection{Event summaries}

Almost all of the heatbursts detected by the Oklahoma Mesonet were underneath or adjacent to weak radar echoes (generally less than $30 \mathrm{dBz}$ ) at the time of the event. Four basic radar patterns (Figure 5) were 


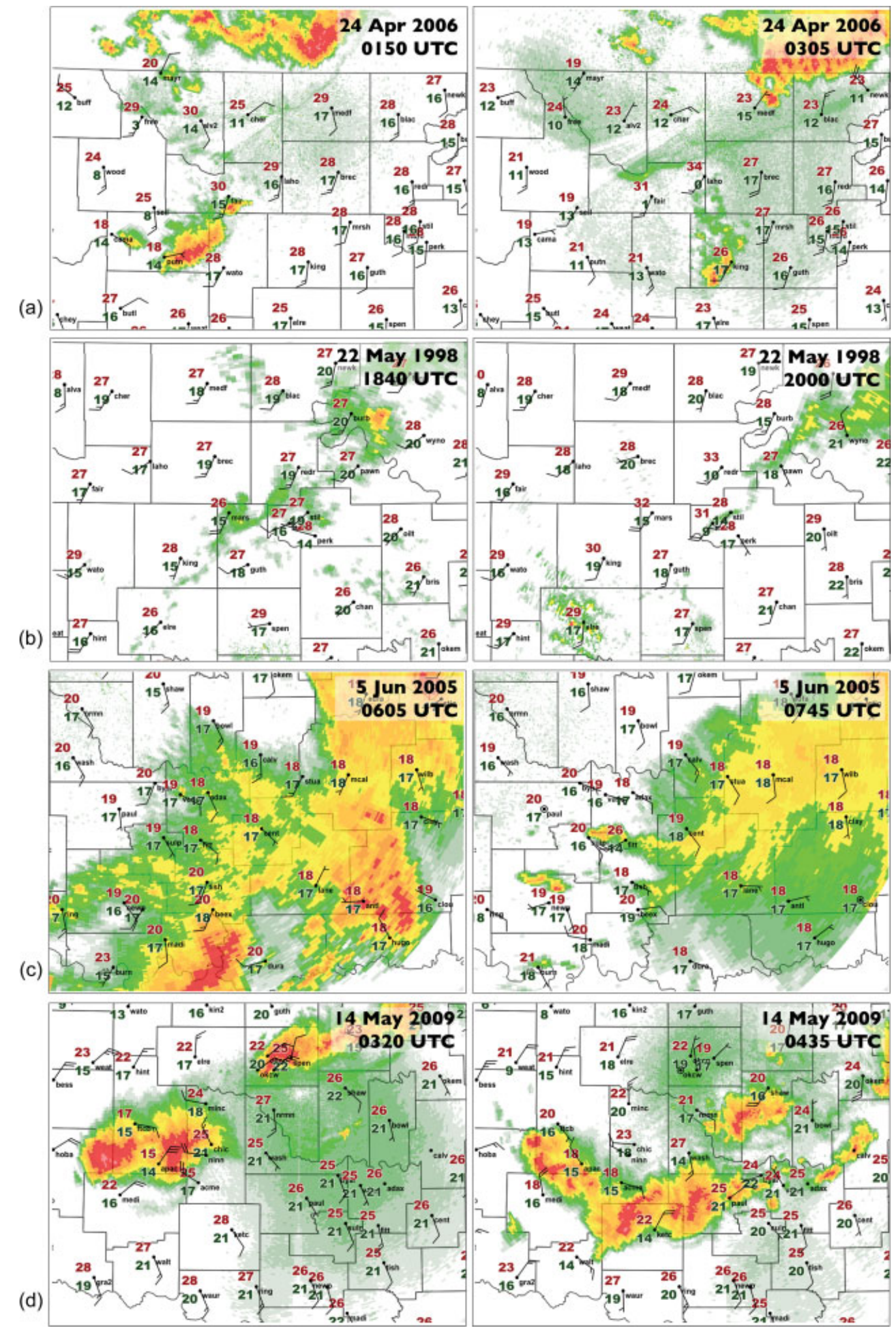

Figure 5. Examples of four basic radar patterns typically associated with Oklahoma heatburst events: (a) radar echoes associated with rapidly weakening convection, (b) weak reflectivity not produced by or associated with deep moist convection, (c) weak radar echoes to the rear of a dissipating MCS, and (d) weak reflectivity along the periphery of intense convection that did not appear to be weakening. This figure is available in colour online at wileyonlinelibrary.com/journal/joc

associated with the events: (1) radar echoes associated with rapidly weakening convection, (2) weak reflectivity not produced by or associated with deep moist convection, (3) weak radar echoes to the rear of a dissipating
MCS and (4) weak reflectivity along the periphery of intense convection that did not appear to be weakening.

The 308 Oklahoma heatburst detections in this study produced the following conditions: 


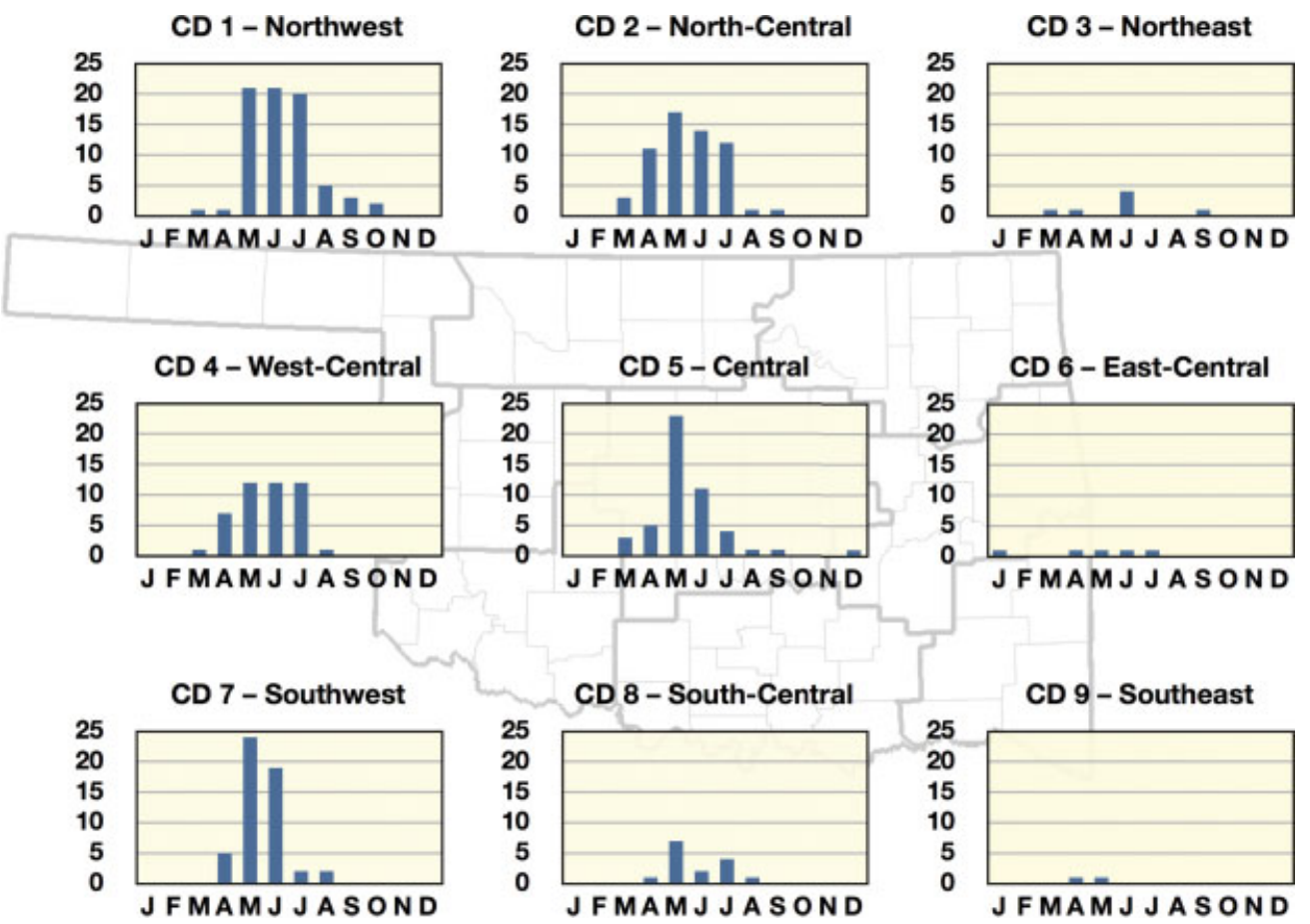

Figure 6. Geographical distribution of heatburst detections by CD across Oklahoma and by month (J, F, M, ... for January, February, March,...) from 1 January 1994 to 15 August 2009. If a heatburst event were measured at 10 Mesonet sites, it was counted as 10 detections. This figure is available in colour online at wileyonlinelibrary.com/journal/joc
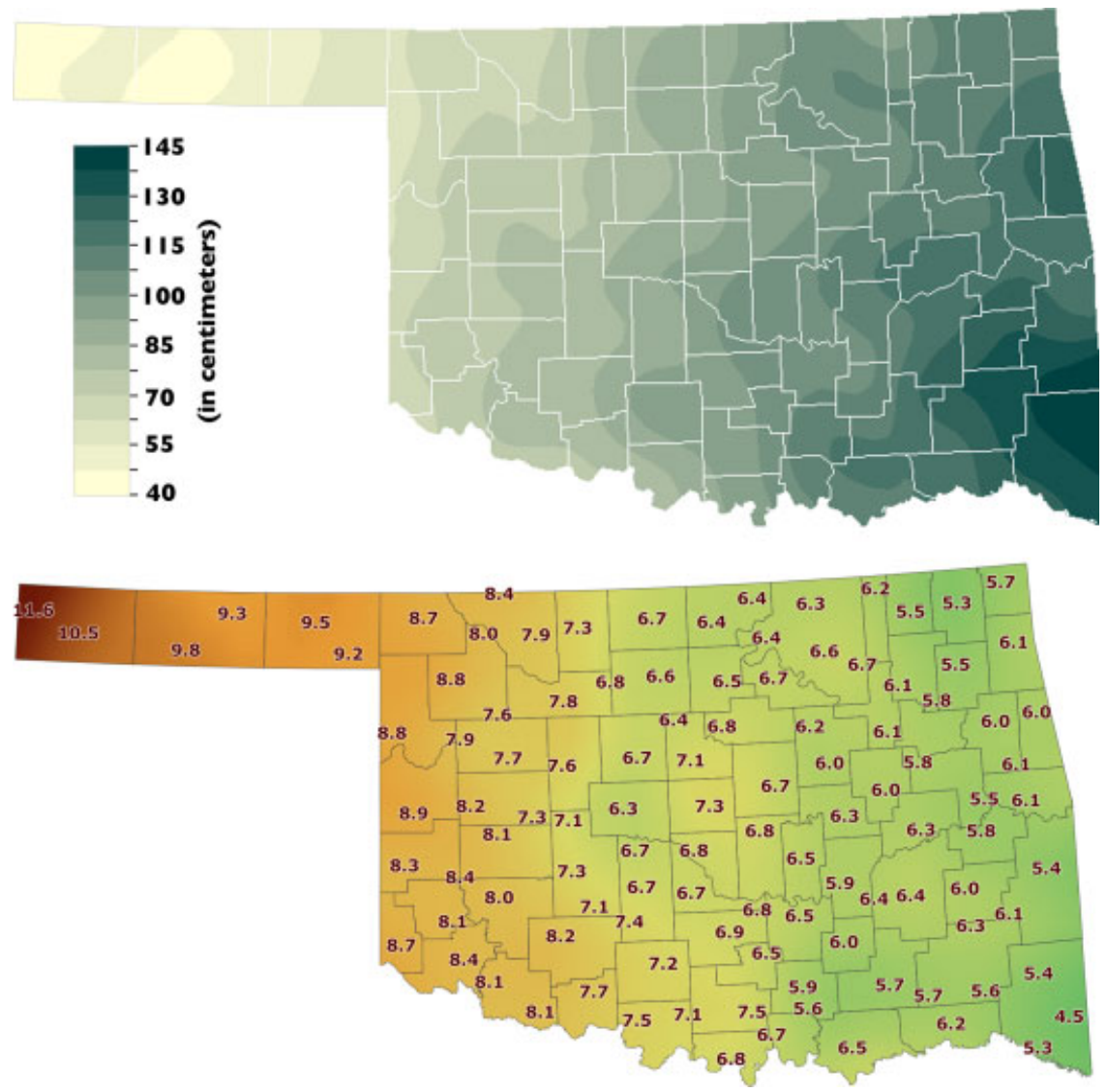

Figure 7. Map of the normal annual total precipitation (top; in centimeters) across Oklahoma for 1971-2000 [data from National Climatic Data Center (NCDC) 2002]. Map of the 15-year average dewpoint depression (bottom; in Celsius) across Oklahoma for 1994-2008 (data from the

Oklahoma Mesonet). This figure is available in colour online at wileyonlinelibrary.com/journal/joc

- an average (median) increase in air temperature of $5.3^{\circ} \mathrm{C}\left(5.0^{\circ} \mathrm{C}\right)$;
- an average (median) decrease in dewpoint temperature of $6.9^{\circ} \mathrm{C}\left(5.9^{\circ} \mathrm{C}\right)$; 
- an average (median) peak wind gust of $18.2 \mathrm{~m} \mathrm{~s}^{-1}$ $\left(17.6 \mathrm{~m} \mathrm{~s}^{-1}\right)$; and

- an average (median) thermodynamic perturbation that lasted $72 \mathrm{~min}$ (50 min).

Perturbation extremes included $11.6{ }^{\circ} \mathrm{C}$ warming (at Waurika on 7 June 2009), $20.4^{\circ} \mathrm{C}$ drying (at Norman on 20 June 1998) and $33.8 \mathrm{~m} \mathrm{~s}^{-1}$ gusts (at Acme on 23 May 1996). The highest rate of temperature increase was $2.14^{\circ} \mathrm{C} \mathrm{min}{ }^{-1}$ at Hobart $\left(10.7^{\circ} \mathrm{C}\right.$ increase from one 5 -min observation to the next) on 23 May 2005. The briefest heatburst at a station lasted only $10 \mathrm{~min}$, while the longest event (23 May 1996) continued for more than $15 \mathrm{~h}$ and was detected at a single station (Fort Cobb) for more than $6 \mathrm{~h}$. The latter heatburst initiated in southwest Oklahoma, and thermodynamic perturbations were measured across almost $25000 \mathrm{~km}^{2}$ by the end of the event. Severe winds (gusts $>25.7 \mathrm{~m} \mathrm{~s}^{-1}$ ) were recorded for 15 of the events.

Temperature perturbations measured at each station were uncorrelated with the duration of the associated events $\left(R^{2}=0.09\right.$ using linear regression), as were the dewpoint perturbations with the duration $\left(R^{2}=0.07\right)$ and the temperature perturbations with the maximum gust $\left(R^{2}=0.05\right)$.

Because the median duration of heatburst condition was $50 \mathrm{~min}$, the hourly real-time observations of NWS Automated Surface-Observing System (ASOS) would be insufficient to verify many events as they occur. Even with 5-min data, ASOS stations were too sparsely distributed across Oklahoma to develop a robust climatology. For example, during 2005, when 26 heatburst events were measured by the Oklahoma Mesonet, only one event was detected (29 June 2005 at Guymon) using archived, 5-min ASOS data. An Oklahoma Mesonet site that was $12 \mathrm{~km}$ away (Goodwell) also detected that event.

\subsection{Spatial distribution}

Figure 6 displays the number of heatbursts detected at each Mesonet site [by climate division (CD)] during the study period. Heatbursts were almost non-existent in the eastern third of the state; yet, they were relatively frequent in northwest Oklahoma.

This geographical distribution of heatburst detections corresponded to the climatological gradient in atmospheric moisture between southeast and northwest Oklahoma (e.g. as represented by normal annual precipitation and average annual dewpoint depression in Figure 7). High-based convection is a common occurrence over the United States High Plains during the late spring and summer. This convection often is rooted in the dry boundary layer. However, elevated convection may develop if a short-wave trough or other mid-tropospheric lifting mechanism interacts with the elevated moist layer characteristics of the 'Type A' sounding. As convective rain descends through the boundary layer (e.g. across western Oklahoma), it evaporates and the adjacent air cools. If the environmental lapse rate is nearly dry adiabatic in

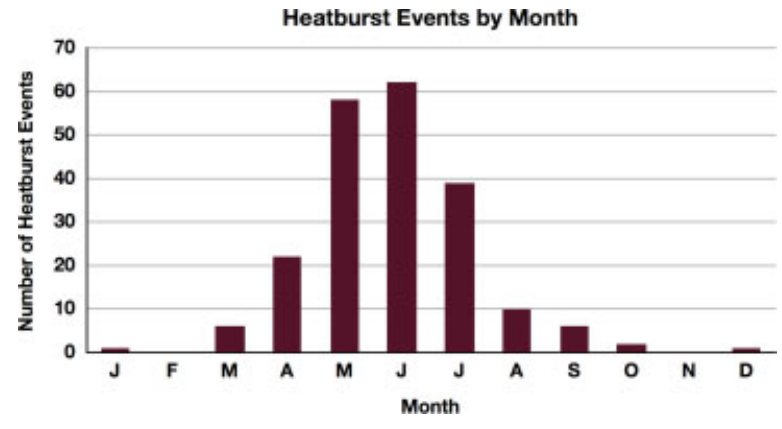

Figure 8 . Number of heatburst events by month, as measured by the Oklahoma Mesonet, for all CDs of Oklahoma from 1 January 1994 through 15 August 2009. This figure is available in colour online at wileyonlinelibrary.com/journal/joc

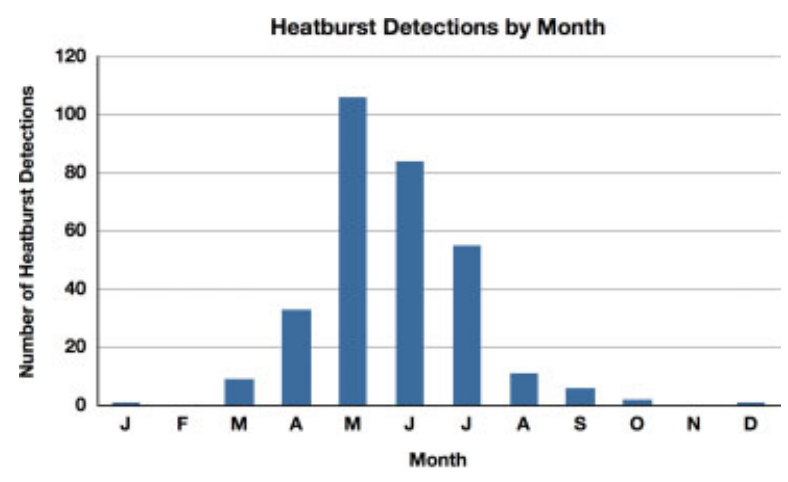

Figure 9. Number of detections of heatbursts at individual Oklahoma Mesonet sites by month for all CDs of Oklahoma from 1 January 1994 through 15 August 2009. If a heatburst event were measured at 10 Mesonet sites, it was counted as 10 detections. This figure is available in colour online at wileyonlinelibrary.com/journal/joc

the sub-cloud layer, all of the rain may evaporate and the descending air will begin to heat by compression, possibly resulting in a heatburst at the ground.

\subsection{Monthly distribution}

Figures 6 and 8 depict heatburst events by month for Oklahoma's nine CDs and for the entire state. Seventyseven percent of heatburst events occurred during May, June and July. With 62 of the 207 events, June was the most active month for heatbursts. At the other extreme, no heatbursts were detected during February and November, and only one was observed during January and December.

Figure 9 displays the heatburst detections at each station by month. Although heatburst events were more common in June, they appeared to be spatially larger when they occurred during May because more stations detected heatbursts in May (Figure 9) even though fewer events occurred (Figure 8). Removal of three large heatburst events during May 1996 (10 May, 15 May and 23 May), however, resulted in a monthly distribution of heatburst detections similar to that of heatburst events (not shown). 


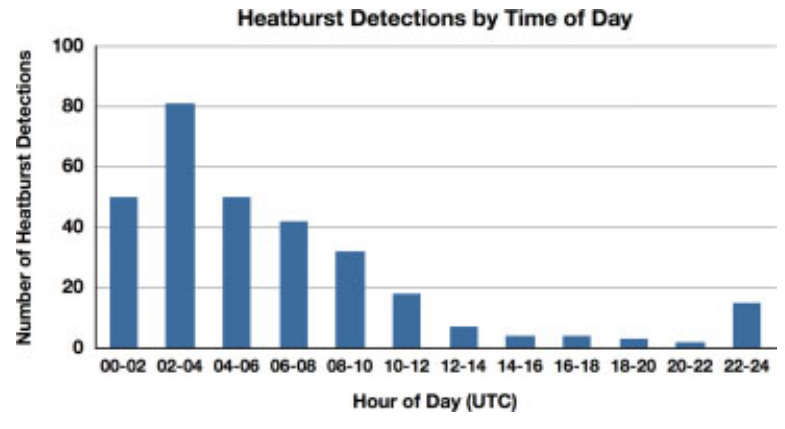

Figure 10. Number of heatburst detections by time of day (e.g. $01=$ 0100 UTC), as measured by the Oklahoma Mesonet, for all CDs of Oklahoma from 1 January 1994 through 15 August 2009. This figure is available in colour online at wileyonlinelibrary.com/journal/joc

\subsection{Frequency by time of day}

Figures 10 and 11 show the heatburst detections in Oklahoma by time of day, revealing a peak of heatburst onset activity between 0200 and 0400 UTC (i.e. between 8 and 10 p.m. Central Standard Time). Heatburst events displayed a similar temporal distribution (not shown). About $70 \%$ of heatburst events and $73 \%$ of heatburst detections initiated between 0000 and 0800 UTC.

Heatbursts once were thought to be exclusively nocturnal in nature, possibly because surface-based inversions were not observed during the daylight hours. However, heatbursts did occur in Oklahoma during the peak of insolation, as indicated in Figure 10. In these rare afternoon (1600-2400 UTC) events, persistent cloud cover could have resulted in a weak stable layer that prevented deep convective mixing in the boundary layer. During any time of the day, thunderstorms could dissipate rapidly if they moved into a more stable environment (e.g. on the cool side of an air mass boundary).

The peak of heatburst activity during early evening corresponded to the typical timing of dissipation of convection during spring and summer across Oklahoma (Wallace, 1975). During the warm season, especially when synoptic forcing and vertical wind shear were weak, deep, moist convection often formed during the afternoon. After sunset, when surface temperatures cooled, instability weakened and convection rapidly dissipated. Eventually, a weak near-surface stable layer might have existed, with dry adiabatic lapse rates between the inversion and the retreating cloud base. In this scenario, air that descended from the dissipating thunderstorm with sufficient negative buoyancy to penetrate the stable layer could have produced a localized downdraft of warm, dry air.

This diurnal cycle of convective dissipation would be most pronounced at and shortly after sunset. In addition, the decrease in heatburst activity into the night also could be attributed to strengthening of the nocturnal inversion. As the inversion strengthened, the likelihood of subsiding air penetrating it decreased.

\section{Discussion}

The criteria used in this study (see Section 3.2) resulted in the detection of heatburst conditions for 308 station/date

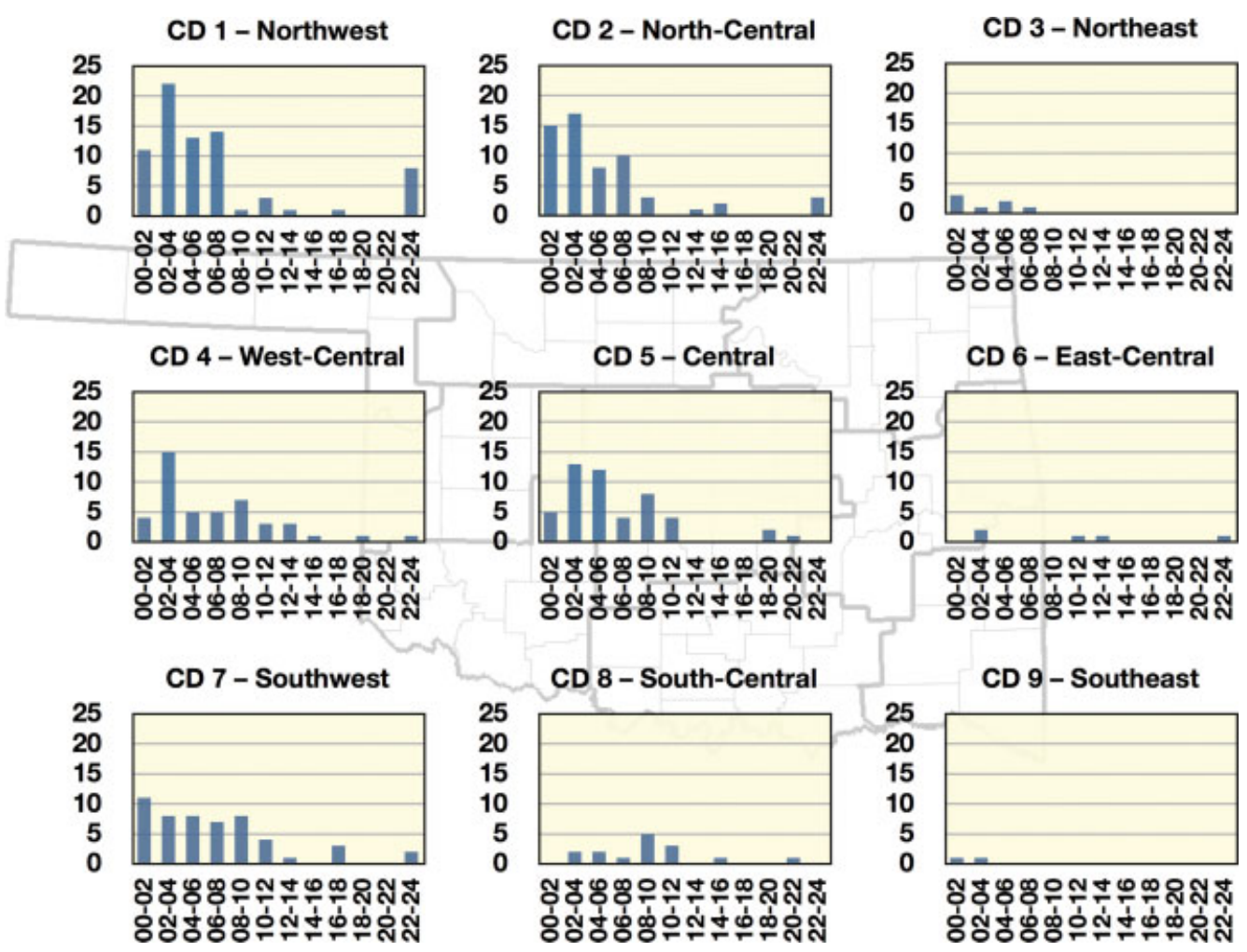

Figure 11. Geographical distribution of heatburst detections by CD across Oklahoma and by time of day (e.g. $01=0100$ UTC) from 1 January 1994 to 15 August 2009. If a heatburst event was measured at 10 Mesonet sites, then it was counted as 10 detections. This figure is available in colour online at wileyonlinelibrary.com/journal/joc 

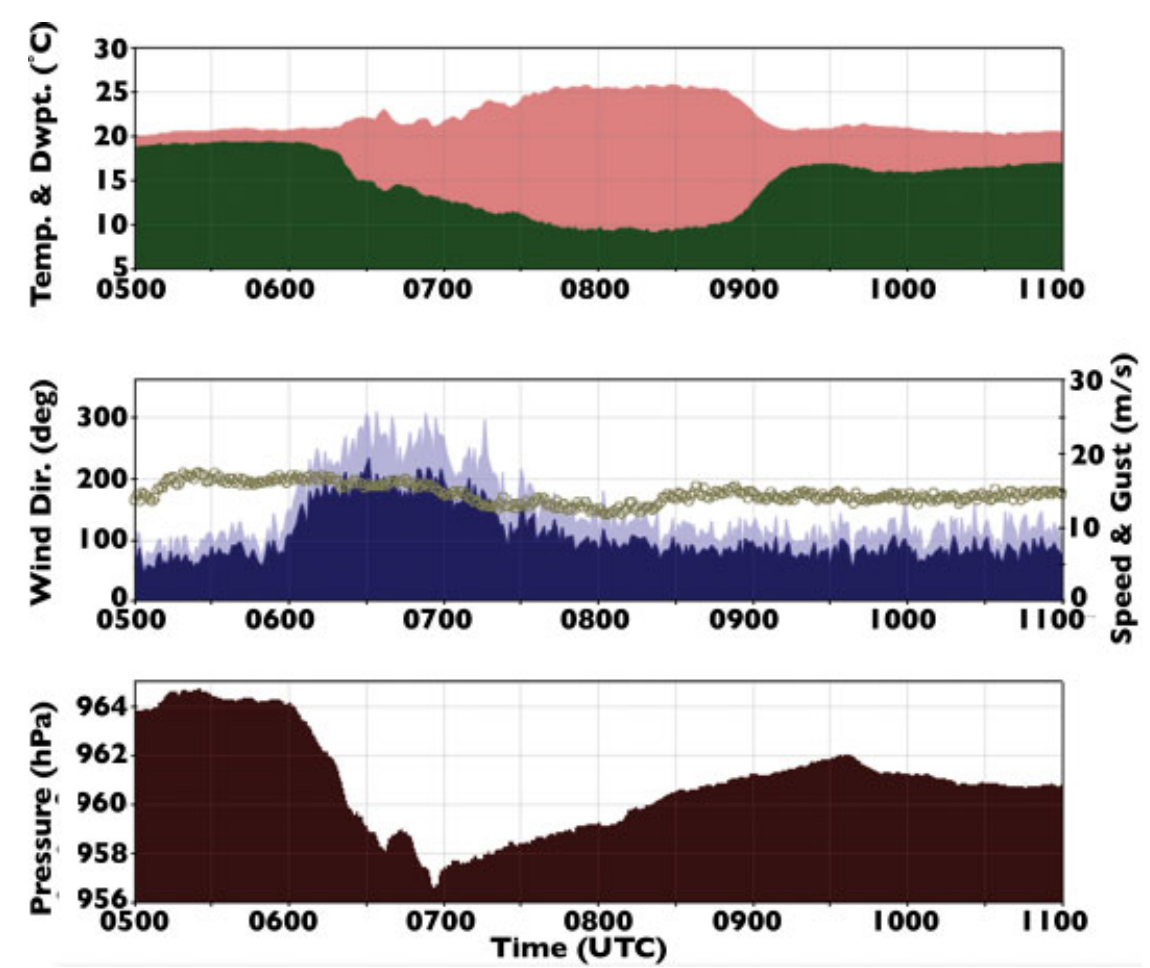

Figure 12. One-minute measurements from the Spencer Mesonet site on 13 May 2009. The top panel represents dry-bulb (light shading) and dewpoint (dark shading) temperatures in degree celsius; the middle panel displays wind speed (dark shading) and gusts (light shading) in $\mathrm{m} \mathrm{s}^{-1}$ as well as wind direction (dots) in degrees from North; and the bottom panel shows station pressure in hPa. Although this study's heatburst criteria were not met at this observing site, the thermodynamic perturbations resulted from a collapsing thunderstorm that did cause the criteria to be met at nearby stations. This figure is available in colour online at wileyonlinelibrary.com/journal/joc

combinations. The criteria also singled out 320 station/date combinations that were not heatbursts, however, and thus cannot be used as the sole method to detect heatburst events in a data archive. In addition, the authors found heatburst events that were not detected using the documented criteria. Examples of how the methodology missed heatburst conditions follow:

- Some heatburst conditions did not develop as quickly as the heatburst criteria defined (i.e. temperature and dewpoint changes over a 10-min period). Examples include 13 June 2002 at Tipton $\left(2.7^{\circ} \mathrm{C}\right.$ temperature change occurred over $15 \mathrm{~min}), 21$ August 2007 at Cherokee (20 min) and 15 June 2009 at Breckinridge (25 min). All of these cases exhibited increased temperature, decreased dewpoint and strong winds near a dissipating thunderstorm complex.

- Some stations measured thermodynamic perturbations during a heatburst, but because they were located on the edge of the event, the magnitude of one or more criteria was not satisfied. For example, on 13 May 2009, measurements at the Bristow, Red Rock, and Shawnee Mesonet sites met the heatburst criteria as a complex of thunderstorms decayed near the stations; however, the nearby Spencer site clearly was affected by the heatburst (Figure 12 with 1-min observations) but only two of three criteria were met (i.e. only $2.1^{\circ} \mathrm{C}$ temperature increase during the entire event).

- In some cases, the wind gusts were higher than $10.0 \mathrm{~m} \mathrm{~s}^{-1}$ but outside of the time period defined in the criteria. A decaying line of storms on 23 May 1999 only resulted in a wind gust of $9.9 \mathrm{~m} \mathrm{~s}^{-1}$ at Buffalo during the specified time frame (i.e. 5 min prior to, during, or 5 min after the temperature and dewpoint change criteria were met), when the temperature increased $2.7^{\circ} \mathrm{C}$ and the dewpoint decreased $5.0^{\circ} \mathrm{C}$. A gust of $14.3 \mathrm{~m} \mathrm{~s}^{-1}$ occurred about $1 \mathrm{~h}$ later, however, as the heatburst continued.

- There were cases when the timing of the perturbations was slightly different from the criteria. For example, in the wake of a decaying thunderstorm complex on 26 May 2008, temperatures increased by $9.3^{\circ} \mathrm{C}$ over $10 \mathrm{~min}$ and winds gusted to $19 \mathrm{~m} \mathrm{~s}^{-1}$ at May Ranch; however, during the 10 -min period of the temperature perturbation, the dewpoint decreased only $2.2^{\circ} \mathrm{C}$. Five minutes later, the 10-min dewpoint decrease was $3.5^{\circ} \mathrm{C}$, but the temperature increase over the same period was only $2.0^{\circ} \mathrm{C}$.

Suggested alternatives to the heatburst detection criteria used in this study include the following: (1) use less restrictive, binary criteria (e.g. $2.5^{\circ} \mathrm{C}$ instead of $2.7^{\circ} \mathrm{C}$ ), (2) implement a dewpoint depression perturbation test instead of a dewpoint perturbation test, (3) implement perturbation tests using equivalent potential temperature and potential wet-bulb temperature and (4) conduct the multi-criteria analysis using fuzzy criteria (Jiang and Eastman, 2000) rather than binary criteria.

In some cases, such as the extremely large 23 May 1996 heatburst (detailed in MacKeen et al., 1998), it was 


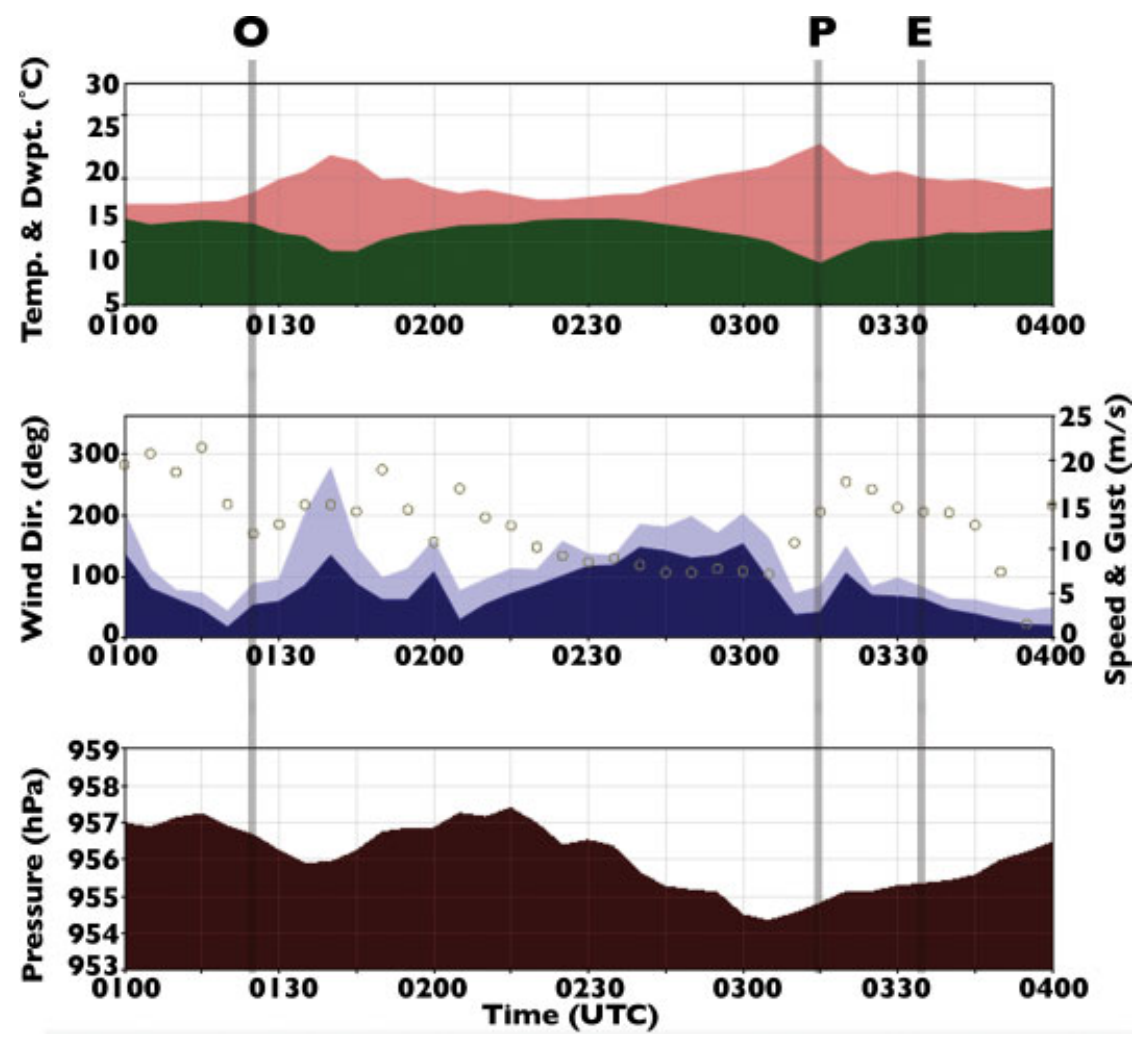

Figure 13. Example of a heatburst event consisting of multiple downdrafts measured at a single station (Mangum on 21 April 2005). The top panel represents dry-bulb (light shading) and dewpoint (dark shading) temperatures in degree celsius; the middle panel displays wind speed (dark shading) and gusts (light shading) in $\mathrm{m} \mathrm{s}^{-1}$ as well as wind direction (dots) in degrees from North; and the bottom panel shows station pressure in $\mathrm{hPa}$. The times of the onset $(\mathrm{O})$, peak $(\mathrm{P})$, and end $(\mathrm{E})$ of the event are labeled. This figure is available in colour online at wileyonlinelibrary.com/journal/joc

not evident how to separate the heatburst event into a downdraft phase, where the thermodynamic perturbations resulted directly from subsidence, and an advection phase, where the hot, dry air was advected to another station. It also was unclear whether this distinction was important for defining the event. Regardless, because of both advection of heatburst conditions to nearby stations and the lateral movement of the heatburst downdraft, the area affected by the heatburst over time typically was larger than the area affected at any given time.

Finally, there were several occasions when the heatburst detection at a given station represented a series of downdrafts, resulting in two or more peaks in the temperature observations (Figure 13). If it were evident that the same decaying thunderstorm caused multiple thermodynamic perturbations, the entire series was considered part of a single heatburst. Hence, the end of the heatburst was designated to be at the end of the series of perturbations. If it were evident that the series of perturbations resulted from different dissipating thunderstorm cells, then each perturbation was considered a different heatburst. There were only two days when the latter scenario occurred; in one case, a station measured two separate heatbursts, and in the other, a station detected three distinct heatbursts.

\section{Summary}

Although rarely captured by synoptic-scale, hourly observing networks, measurements from the Oklahoma Mesonet suggest that heatbursts have been somewhat common in semi-arid western Oklahoma. The mesoscale network's 5-min temporal resolution and 32-km average spatial resolution provided a significant data set to analyse these mesoscale events.

Using a multi-criteria analysis, 308 heatburst detections that represented 207 heatburst events were documented from 1 January 1994 to 15 August 2009. Most heatbursts were associated with collapsing thunderstorms or subsidence behind convective complexes. Typically, these events occurred during the evening or night from May through July.

This study establishes a base climatology of heatbursts across Oklahoma and may represent the frequency, duration, seasonality and magnitude of currently undetected heatbursts throughout the semi-arid Southern Great Plains of the United States. In addition, these events may be more common than previously considered, but with a different seasonality, in parts of the US High Plains. Without a permanent surface-observing system with high spatial and temporal resolution across other states in these regions, most heatbursts will remain undetected. 


\section{Acknowledgements}

Oklahoma's taxpayers fund the Oklahoma Mesonet through the Oklahoma State Regents for Higher Education and the Oklahoma Department of Public Safety. The Oklahoma Climatological Survey and NOAA's National Climatic Data Center provided archived radar data for verification. The authors thank Jared Bostic, David Demko, Brad Illston, Dillon McClain, Alex McCombs and Cindy Morgan for their help with obtaining or quality assuring the observations. Thanks also are extended to Mike Jackson of the NWS Forecast Office in Greer, South Carolina, for his assistance in obtaining and displaying the 5-min ASOS data.

\section{References}

Azorín Molina C. 2005. Situación atmosférica de "heat burst" en la provincia de Alicante. Ería 67: 237-254.

Bernstein BC, Johnson RH. 1994. A dual-doppler radar study of an OK PRE-STORM heat burst event. Monthly Weather Review 122: 259-273.

Brock FV, Crawford KC, Elliott RL, Cuperus GW, Stadler SJ, Johnson HL, Eilts MD. 1995. The Oklahoma Mesonet: a technical overview. Journal of Atmospheric and Oceanic Technology 12: 5-19.

Caracena F, McCarthy J, Flueck JA. 1983. Forecasting the likelihood of microbursts along the front range of Colorado. 13th Conference on Severe Local Storms, Tulsa, OK, American Meteorological Society, $261-264$.

Cline IM. 1909. Climatological data for July, 1909, district no. 7, lower Mississippi Valley. Monthly Weather Review 37: 337-338.

Cunningham D. 1989. Rapid changes of pressure and temperature, Guernsey, 31 July 1983. Weather 44: 131-133.

Froude GJ, Simmonds J. 1965. Phenomenal temperature oscillations in Aden. Meteor. Mag 94: 185-187.

Fujita TT. 1978. Manual of downdraft identification for Project NIMROD. SMRP Res. Paper 156, University of Chicago, 104.

Fujita TT, Caracena F. 1977. An analysis of three weather related aircraft accidents. Bulletin of the American Meteorological Society 58: $1164-1181$.

Fujita TT, Byers HR. 1977. Spearhead echo and downburst in the crash of an airliner. Monthly Weather Review 105: 129-146.

Jiang H, Eastman JR. 2000. Application of fuzzy measures in multicriteria evaluation in GIS. International Journal of Geographical Information Sciences 14: 173-184.
Johnson BC. 1983. The heat burst of 29 May 1976. Monthly Weather Review 111: 1776-1792.

Johnson JS. 2004. Examination of a long-lived heat burst event in the northern plains. National Weather Digest 27: 27-34.

Johnson RH, Chen S, Toth JJ. 1989. Circulations associated with a mature-to-decaying midlatitude mesoscale convective system. Part I: Surface features - heat bursts and mesolow development. Monthly Weather Review 117: 942-959.

Lane JD. 2000. A climatology of heatbursts as detected by the Oklahoma Mesonet: October 1993 through September 1998. M. S. Thesis, University of Oklahoma, Norman, 141. [Available from National Weather Center Library, Room 4300, 120 David L. Boren Boulevard, Norman, OK 73072].

MacKeen P, Andra DL, Morris DA. 1998. The 22-23 May 1996 heatburst: a severe wind event. Preprints, $19^{\text {th }}$ Conf.Severe Local Storms, Minneapolis, Amer. Meteor. Soc., 510-513.

Malczewski J. 1999. GIS and Multicriteria Decision Analysis. Wiley: New York; 408.

McNulty RP. 1991. Downbursts from innocuous clouds: an example. Weather and Forecasting 6: 148-154.

McPherson RA, Fiebrich CA, Crawford KC, Elliott RL, Kilby JR, Grimsley DL, Martinez JE, Basara JB, Illston BG, Morris DA, Kloesel KA, Stadler SJ, Melvin AD, Sutherland AJ, Shrivastava H. 2007. Statewide monitoring of the mesoscale environment: A technical update on the Oklahoma Mesonet. Journal of Atmospheric and Oceanic Technology 24: 301-321.

NCDC. 2002. Climatography of the U.S. No. 81: Monthly station normals of temperature, precipitation, and heating and cooling degree days 1971-2000. National Climatic Data Center, CD-ROM. [Available online at http://nndc.noaa.gov/onlinestore.html.].

Sloan YT. 1966. An unusual temperature fluctuation at Midland, Texas. Southern Region Report 3, U.S. Weather Bureau, Washington, D.C., 9-12.

Trobec J. 2008. Heat burst detection by a temporally fine-scale mesonet. NWA Electronic Journal of Operational Meteorology 2008: EJ1.

Wakimoto RM. 1985. Forecasting dry microburst activity over the High Plains. Monthly Weather Review 113: 1131-1143.

Wallace JM. 1975. Diurnal variations in precipitation and thunderstorm frequency over the conterminous United States. Monthly Weather Review 103: 406-419.

Williams DT. 1963. The thunderstorm wake of May 1961. National Severe Storms Project Report 18, U.S. Department of Commerce, Washington, D.C., 23.

Wood RA. 1966. A thunderstorm "warm wake" at Midland, Texas. Southern Region Report 3, U.S. Weather Bureau, Washington, D.C., $1-7$. 